\title{
Freshwater sponges (Porifera, Demospongiae) indicators of some coastal habitats in South America: redescriptions and key to identification
}

\author{
Cecilia Volkmer-Ribeiro \& Vanessa de Souza Machado
}

Museu de Ciências Naturais, Fundação Zoobotânica do Rio Grande do Sul, Caixa Postal 1188, 90001-970 Porto Alegre, RS, Brazil. (cvolkmer@fzb.rs.gov.br)

\begin{abstract}
Surveys for freshwater sponges were performed at several water bodies at sandy environments along a north-south direction of particularly the Brazilian coastal line. The results allowed for the distinction of four different species-specific environments along this coastal border. The main fact considered was the dominant or the sole recurrent occurrence of a single sponge species at one particular habitat. The first one is that of the lagoonal mesohaline habitats at the tropical and subtropical realms, indicated by Spongilla alba Carter, 1849. The second one refers to shallow ponds among dunes at the tropical area indicated by Corvoheteromeyenia heterosclera (Ezcurra de Drago, 1974). The third one is that of also shallow ponds close to the dune belt at the temperate region indicated by Racekiela sheilae (Volkmer-Ribeiro, De Rosa-Barbosa \& Tavares, 1988). The fourth one is that of organically enriched environments, at the marginal areas of lagoons and mouth of small rivers, evolving towards freshwater muddy ponds and coastal swamps, not far from the ocean border: Ephydatia facunda Weltner, 1895 is the species to occupy this habitat with almost exclusiveness. The above species are thus proposed as indicators of such habitats and have their descriptions improved and that of their environments summarized. A taxonomic key based on the spicules of the four species is proposed. The results presented aim to contribute to the identification of spicules of these sponges in sediment columns recovered at the Brazilian and South American coastal area. Determination of paleo ocean borders are a present issue of upmost importance in what respects projections of timing and fluctuations of ascending/regressing sea levels.
\end{abstract}

KEYWORDS. Freshwater sponges, indicator species, sandy coastal environments, paleo-reconstructions, South America.

RESUMO. Esponjas de água doce (Porifera, Demonspongiae) indicadoras de alguns ambientes costeiros na América do Sul: redescrição e chave para identificação. Levantamentos para detecção de esponjas dulcícolas foram conduzidos em diversos corpos d'água da faixa arenosa costeira, de norte a sul, particularmente no Brasil. Os resultados permitiram a distinção de quatro ambientes específicos em relação à presença de certas espécies, considerando-se como fator determinante a ocorrência recorrente, exclusiva ou preponderante de uma espécie nos tipos de habitats examinados. O primeiro grupo é o de habitats mesohalinos de lagunas, nas faixas tropical e subtropical, indicado por Spongilla alba Carter, 1849. O segundo é constituído por lagoas rasas, entre dunas, situado na faixa tropical, com a presença de Corvoheteromeyenia heterosclera (Ezcurra de Drago, 1974). O terceiro é o de lagoas/banhados, também rasos, vizinhos ao cordão de dunas, na região temperada, com Racekiela sheilae (Volkmer-Ribeiro, De Rosa-Barbosa \& Tavares, 1988). O quarto é constituído por ambientes organicamente enriquecidos, nas áreas marginais de lagunas e proximidades de barras de pequenos rios, evoluindo para lagoas e banhados em processos de colmatação, com fundos lodosos, não distantes da borda oceânica, com a presença quase exclusiva de Ephydatia facunda Weltner, 1895. Essas espécies são por isto propostas como indicadoras de tais habitats, promovendose a ampliação de suas descrições e a caracterização sintética desses ambientes. É proposta chave para identificação baseada nas espículas dessas esponjas. Os resultados apresentados visam contribuir para a identificação de suas espículas em colunas de sedimentos recuperados em áreas costeiras do Brasil e da América do Sul. As determinações de paleobordas oceânicas integram estudos com alto grau de interesse no que respeita a projeções temporais e flutuações de níveis ascendentes/regressivos dos oceanos.

PALAVRAS-CHAVE. Esponjas continentais, espécie indicadora, ambientes costeiros, paleo-reconstruções, América do Sul.

The wide ranging inventory of Brazilian, in particular, and South American, in general, freshwater sponges is demonstrating that species or assemblages of this fauna present a recurrent occurrence in some specific continental habitats or even biomes. This fact has enhanced the proposition of such species as indicators of several South American freshwater environments as, for instance: Cerrado ponds (VOLKMERRibeiro \& MotTA, 1995, VolKMER-Ribeiro et al., 1988b), floating meadwos (TAVARES et al., 2003), Amazonian clear water flood plain lakes and rocky river beds (BATISTA et al., 2003), Amazonian "igapós": black water flood plain lakes (VolKMER-Ribeiro \& Almeida, 2005), Uruguay and Paraná rivers rocky beds (BonetTo \& EzCuRRA DE Drago, 1970; Batista \& Volkmer-Ribeiro, 2002). These propositions fulfill two main purposes: the first is that of using such species in projects of biodiversity monitoring or its recovering processes in the above mentioned environments. The second one has to do with the growing use the silicous spicules of freshwater sponges are having in paleo-reconstructions, once they are detected in recovered Quaternary sediments (HARRISON, 1988; TuRCQ et al., 1998; CANDIDO et al., 2000; GAISER et al., 2004; VolKMER-RIBEIRO et al., 2006). Recent studies are showing that some fresh water sponges also exhibit recurrent occurrences in certain Atlantic coastal environments of South America. These refer to typical aquatic (TERMIER \& TERMIER, 1963) environments resulting at the continental borders upon the sea level regression and sand depositional processes which gave place to lagoons, freshwater ponds and wetlands or yet freshwater ponds formed amidst the dune belt. Several such environments were surveyed for their sponge fauna along this extensive coastal line. The species which 
exhibited recurrent/dominant occurrences at the same kind of habitat are now proposed as indicators of such environments, bearing in mind the identification of their spicules in sediment columns recovered at the Atlantic edge of the continent and their use in paleoreconstructions and studies of timing of the ocean ingression/regression processes at this edge. For this purpose, a taxonomic key based on the spicules of these species is presented. At the same time their descriptions are given and their respective habitats identified.

\section{MATERIAL AND METHODS}

Surveys for freshwater sponges were performed at several water bodies at the sandy belt along a northsouth direction, mostly at the Brazilian costal line. The surveys were manually performed or gemmules were detected in sediments caught with an Ekman dredge. Preparations of dissociated spicules of the specimens and gemmules were done according to VoLKMER-RIBEIRO (1985) for studies with light optical microscopy and for scanning electron microscopy (SEM) (VoLKMER-RIBEIRo \& TURCQ, 1996). Also, camera-lucida drawings were made of the spicular components in order to obtain illustrations for the taxonomic key. The minimum, maximum and mean length and width of the spicules as well as the standard deviation were calculated based on the measurements obtained from 50 megascleres, gemoscleres and microscleres of several studied specimens of each species. The SEM photographs were obtained at the Electron Microscopy Laboratory of Pontifícia Universidade Católica do Rio Grande do Sul, Porto Alegre and later treated and mounted with the use of computer graphics. Digital images of representative specimens of each of the four species were also produced. The definitions of the spicule categories follow VOLKMERRibeiro \& Pauls (2000).

\section{RESULTS AND DISCUSSION}

The results allowed for the distinction of four different species-specific environments along this coastal border. Most interesting is that this listing agrees with the evolving sediment accumulation processes which take place along regressive ocean lines (TERMIER \& TERMIER, 1963) starting with lagoons and evolving into closed freshwater lakes and ponds and into muddy, organic rich freshwater wetlands. The four later environments / sponge species associations are: 1. tropical and subtropical lagoonal mesohaline habitats, indicated by Spongilla alba Carter, 1849; 2 . shallow ponds among dunes at the tropical area indicated by Corvoheteromeyenia heterosclera (Ezcurra de Drago, 1974); 3. shallow ponds boundaring the continental side of the dune belt at the temperate region, indicated by Racekiela sheilae (Volkmer-Ribeiro, De Rosa-Barbosa \& Tavares, 1988); 4. organically enriched environments, at the marginal areas of lagoons and mouth of small rivers, evolving towards freshwater muddy-acid ponds and coastal swamps, not far from the ocean border, where Ephydatia facunda Weltner, 1895 is the species occupying the habitat almost exclusively.
Identification key for freshwater sponges indicators of South American coastal aquatic habitats based on microscleres and gemoscleres present in recovered sediments:

1. Microscleres present ................................................. 2

1'. Microscleres absent ................................................... 3

2. Microscleres of two classes: minute umbonated birotulates with smooth shafts capped by a circle of few irregular hooks curved towards the shaft; and longer, slender birotulates with straight, spiny shafts and small rotules regularly cut in a number of minute teeth. These rotules may be so reduced to the point that this microsclere turns into an strongyle with straight or curved, irregularly spined shaft

Corvoheteromeyenia heterosclera (Fig. 1)

2'. Microscleres in one single class of large, straight to slightly curved, heavily spined oxea with larger spines at the middle portion

Spongilla alba (Fig. 2)

3. Gemoscleres in two classes of birotulates differing in shape and size. The longer is rarer and has stout, straight, spiny shafts and small umbonated rotules deeply cut into an irregular number of hooks, strongly bent towards the shaft. The shorter, predominant, has a slender, short, smooth to spiny shaft, the spines placed at the middle part of the shaft; rotules flat, irregularly deeply and cut in a number of large, straigth spines

Racekiela sheilae (Fig. 3)

3'. Gemoscleres birotulates in a single, extremely variable class, displaying stout to slender, spiny to smooth short shafts, and flat rotules, deeply or slightly cut into an irregular number of spines, disparate in size and shape Ephydatia facunda (Fig. 4)

\section{Corvoheteromeyenia heterosclera (Ezcurra de Drago, 1974)}

(Figs. 1, 5-8, 21, 22)

Material examined. VENEZUELA, Anzoátegui: Clarines (seasonal swamp near River Unare), 16.V.1981, G. Pereira col (MCN-POR 1187); Miranda: Parque Nacional Guatopo, 30.XI.1982, G. Pereira col. (MCN-POR 1188, 1189). BRAZIL, Maranhão: Tutóia (Lagoa do Vidro - Vila de Tutóia), 21.X.1995, C. Volkmer-Ribeiro \& S. Branha col. (MCN-POR 3829, 3840); (Lagoa da Ponta do Arpoador), 24.X.1995, C. Volkmer-Ribeiro \& S. Branha col. (MCN-POR 3830 - 3839); Santo Amaro (Lagoa do Cajueiro), 30.X.1995, C. Volkmer-Ribeiro col. (MCN-POR 3853); Barreirinhas (Lagoa da Pedra), 30.X.1995, C. VolkmerRibeiro col. (MCN-POR 3855, 3856); Lagoa das Vassouras (right bank of the River Preguiças), 21.XI.1999, C. Volkmer-Ribeiro col. (MCN-POR 4270).

Description. Sponge forming fragile crusts on submerged portions of the aquatic vegetation. Live specimens may be green, due to association with algae. Specimens from minute to large, brittle when dry, yellowish, displaying flabelliform shapes due to the coalescence of the skeletal fibres attached to the fan-like leaves of small macrophytes (Fig. 21). Surface irregular with oscular sieves. The skeleton is a reticulum of very open and irregular meshes of monospicular fibres, 


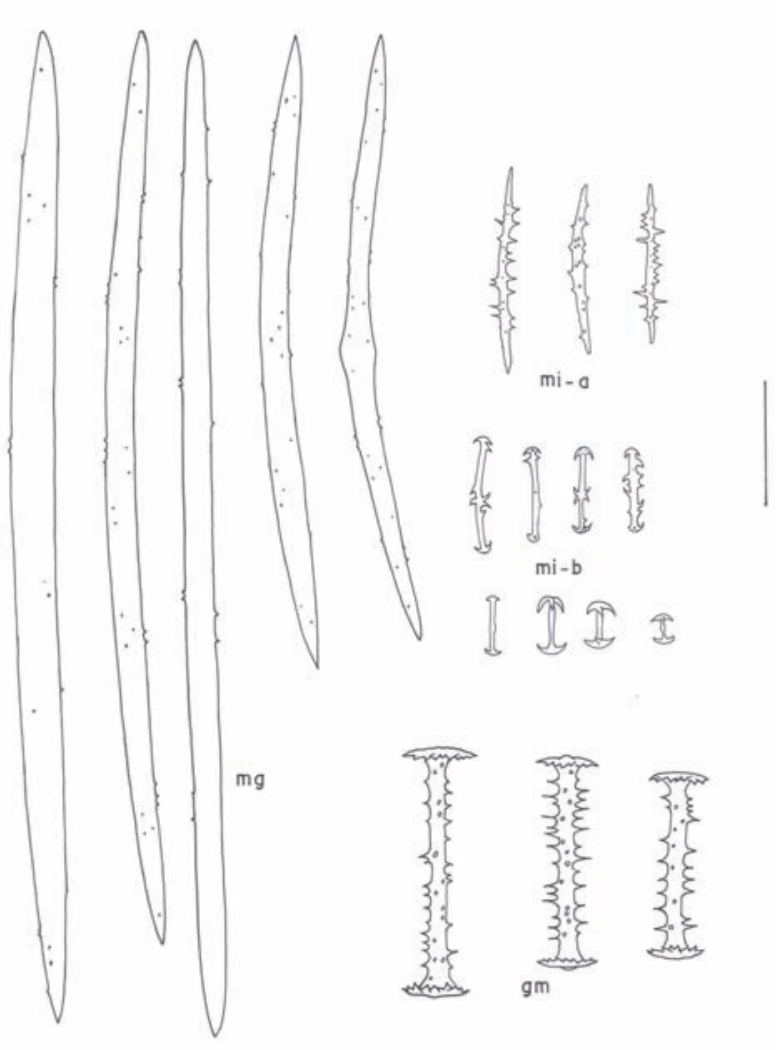

Fig.1. Spicules of Corvoheteromeyenia heterosclera (Ezcurra de Drago, 1974) (mg, megascleres; gm, gemoscleres; mi-a, large microscleres; mi-b, small microscleres). Scale: $50 \mu \mathrm{m}$.

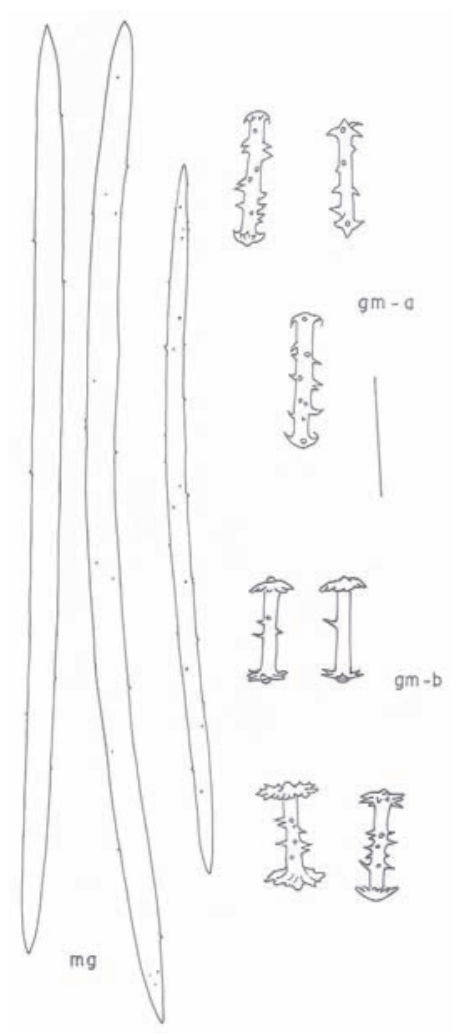

Fig. 3. Spicules of Racekiela sheilae (Volkmer-Ribeiro et al., 1988) (mg, megascleres; gm-a, large gemoscleres; gm-b, small gemoscleres). Scale: $50 \mu \mathrm{m}$.

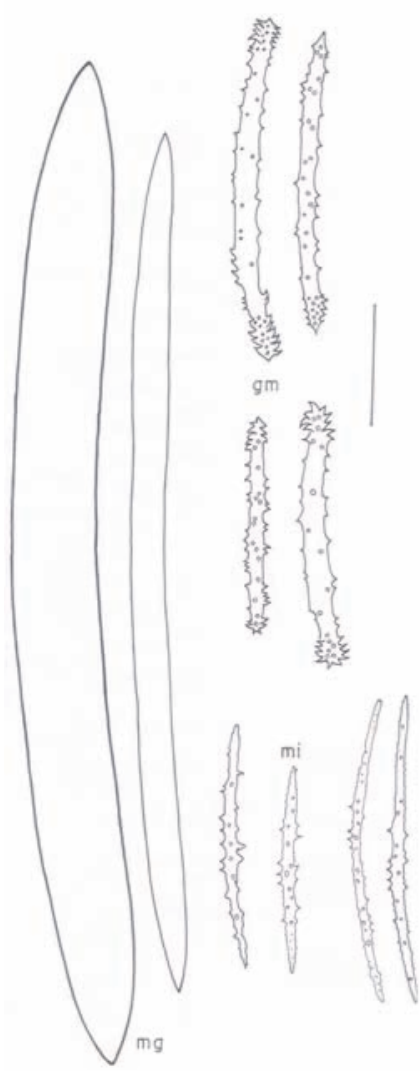

Fig. 2. Spicules of Spongilla alba Carter, 1849 (mg, megascleres; gm, gemoscleres; mi, microscleres). Scale: $50 \mu \mathrm{m}$.

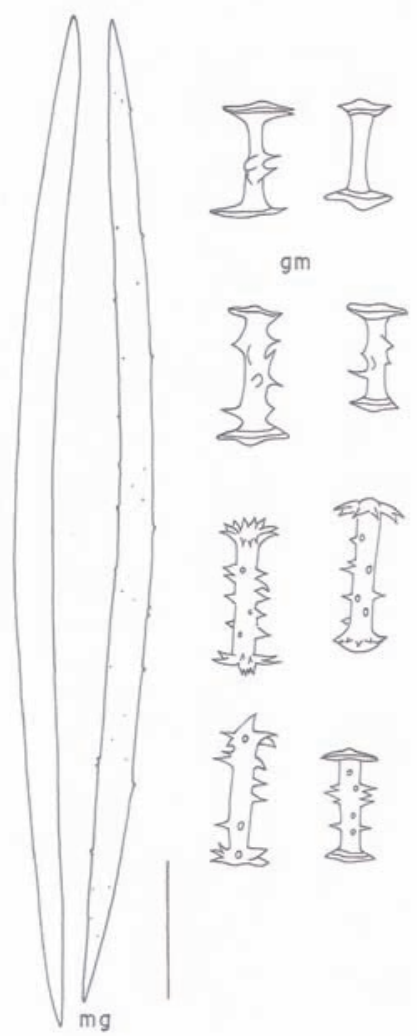

Fig. 4. Spicules of Ephydatia facunda Weltner, 1895 (mg, megascleres; gm, gemoscleres). Scale: $50 \mu \mathrm{m}$. 
encompassing sand grains of various sizes. Megascleres, two categories of microscleres and occasionally also gemoscleres may be found in the skeletal fibers. Megascleres are anfioxea with gradually tapering extremities, from straight to slightly curved, slightly centrotylote, from smooth to microspined. Microscleres of two classes: smaller umbonated birotules with smooth shafts capped by minute rotules with the border cut in a few irregular hooks curved towards the shaft; longer, slender birotules with straight, spiny shafts and small rotules regularly cut in a number of minute teeth, the rotules may however be so reduced that the spicule turns into a strongyle with straight or curved, irregularly spined shaft. Gemoscleres are anfidiscs of uniform size and shape, with almost flat rotules finely cut into small teeth, shafts with abundant spines with crosshead endings (Fig. 5). Gemmules abundant, distributed throughout the reticulum of the sponge, reflecting the temporary nature of the environment; they are hemispherical (Fig. 6), whitish, and provided with a single foraminal tube (Fig. 7). Gemoscleres radially arranged in the thick pneumatic layer. Fully formed gemmules with a thick outer layer (Fig. 8). Spicule measurements in Table I.

This is the only sponge species in the seasonal ponds formed on the inner face of the dune belt closer to the sea, in the geomorphological landscape named Lençóis Maranhenses (northeastern of Brazil), part of which is preserved in the Parque Nacional dos Lençóis Maranhenses (VOLKMER-RIBEIRO et al., 1999), and in other lakes/ponds of the same kind along the northeastern coast of Brazil (Fig. 22). It must be stressed that the species original description (EzCURRA DE DRAGO, 1974) was carried upon material collected at this same region. Volkmer-Ribeiro \& Pauls (2000) registered $C$. heterosclera for the seasonal pools in the vicinity of the river Unare (Clarines), on the coastal area of Venezuela.

Typical environment. Seasonal, shallow freshwater ponds, at the tropical range, with crystalline waters and little macrophyte vegetation (Fig. 22) enclosed among the moving dunes that lay closer to the beach line (VolKMER-Ribeiro et al., 1999). The Parque Nacional dos Lençóis Maranhenses, MA, Brazil (2 $20^{\circ}-2^{\circ} 45^{\prime} \mathrm{S}, 42^{\circ} 45^{\prime}$ $43^{\circ} 30^{\prime} \mathrm{W}$ ) is an example of this environment.

\section{Spongilla alba Carter, 1849}

(Figs. 2, 9-12, 23, 24)

Material examined. VENEZUELA, Zulia: Maracaibo (Lake Maracaibo), 07.VI.1978, students of the Instituto de Zoologia Tropical, Universidad Central de Venezuela col. (MCN-POR 2934). BRAZIL, Alagoas: Maceió (Lagoa Mundaú), 16.XII.1984, 20.VI.1985, 10.III.1985, G. Johnscher-Fornasaro col. (respectively, MCN-POR 1555, 1558, 1565); Santana do Ipanema (Rio Ipanema), 19.II.1995, L. C. F. Alvarenga \& C. N. Ricci col. (MCN-POR 3017 - 3023); Rio de Janeiro: Quissamã / Campos de Goytacazes (Lagoa Feia), 12.I.1982, L. C. F. Alvarenga col. (MCN-POR 1120); Rio de Janeiro (Jacarepaguá), 3.VI.1940, E. H. Cordero col. (MCN-POR 1271).

Description. Sponge forming delicate crusts, of variable size, thickness and shape, on stones or mollusc valves/shells. Dry specimens grey, white or yellow (Fig. 23 ), when living may be dark green. Skeleton with an isodictial reticulum, oscules conspicuous and numerous; the reticulum however, undergoes modifications, and may show main fibers in thicker crusts. Skeleton fibers composed of straight to slightly curved, gradually very sharp pointed smooth anfioxea, microscleres are profusely spined oxeas with larger spines at the middle portion. Microscleres profusely encrust the surface of the sponge and the reticulum fibres and may surpass the size of the gemoscleres. Gemoscleres are spined birotulates with minute rotules cut in an irregular number of small curved spines (Fig. 9). Gemmules abundant, whitish, large, spherical (Fig. 10) or concave, distributed throughout the reticulum. The fully developed gemmules have a thick outer layer which may conceive the foraminal tube. Foraminal tube long and straight (Fig. 11), pneumatic layer thick with gemoscleres embedded in a disorderly manner (Fig. 12). Spicule measurements in Table II.

VOLKMER-RIBEIRO \& TAVARES (1990) registered Spongilla alba throughout the Sistema Lagunar MundaúManguaba, State of Alagoas, including the mesohaline portion, up to the sea border. The record was based on the identification of gemmules found in sediments dredged in order to study the benthic communities of these lagoons. Following the synonymization of Spongilla wagneri Potts, 1889 in S. alba (POIRRIER, 1976), the distribution of S. alba was extended to the states of Rio de Janeiro (WELTNER, 1895) and Amazonas (PENNEY \& RACEK, 1968), presumably at coastal areas. Specimen MCN-POR 1120 now confirms the record of the species for a coastal area at the State of Rio de Janeiro. The present study also confirms the preference of $S$. alba for circum-tropical mesohaline environments as previously indicated by HARRISON (1974) and sums up to the illustration and data on the species offered by VolKMER-RIBEIRo \& TRAVESET (1987) and VOLKMER-RIBEIRO \& REITNER (1991).

Typical environment. Mesohaline environments (HARRISON, 1974), at the tropical and subtropical realms, with particular emphasis on lagoons, are the ones where $S$. alba appears as the dominant species. The Sistema Lagunar

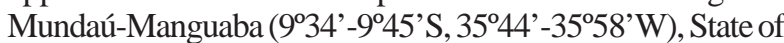
Alagoas, Brazil (Fig. 24) (VolKMER-RIBEIRO \& TAVARES, 1990), as well as Lagoa Feia at Rio de Janeiro are typical examples of this environment. The occurrence of the sponge in the Ipanema River, in the Caatinga region, is explained by the fact that this river dries completely (L. C. F. Alvarenga, pers. comm.), as the crusts of the sponge were detached from large stones on the completely dry river bed. On such occasions, the natural percentage of salts is concentrated in the river water becoming as the drought progresses, brackish or mixohaline.

Table I. Spicule micrometries for Corvoheteromeyenia heterosclera (Ezcurra de Drago, 1974): MCN-POR 1187, 1189, 3832, 4270 (Min, minimum; Max, maximum; Ave, average; SD, standard deviation). All measures in $\mu \mathrm{m}$

\begin{tabular}{lrrrrrrrr}
\hline & \multicolumn{3}{c}{ Megascleres } & \multicolumn{2}{c}{ Gemoscleres } & \multicolumn{2}{c}{ Micro small } & \multicolumn{2}{c}{ Micro large } \\
\hline & Length & Width & Length & Width & Length & Width & Length Width \\
Min & 196.1 & 7.7 & 69.0 & 4.1 & 13.4 & 0.4 & 40.2 & 1.4 \\
Max & 562.4 & 19.9 & 137.1 & 7.9 & 32.8 & 3.8 & 119.5 & 5.3 \\
Ave & 389.1 & 15.3 & 106.5 & 6.0 & 22.2 & 1.4 & 75.8 & 3.4 \\
SD & 103.7 & 2.3 & 17.5 & 0.7 & 3.5 & 0.5 & 17.2 & 0.7 \\
\hline
\end{tabular}




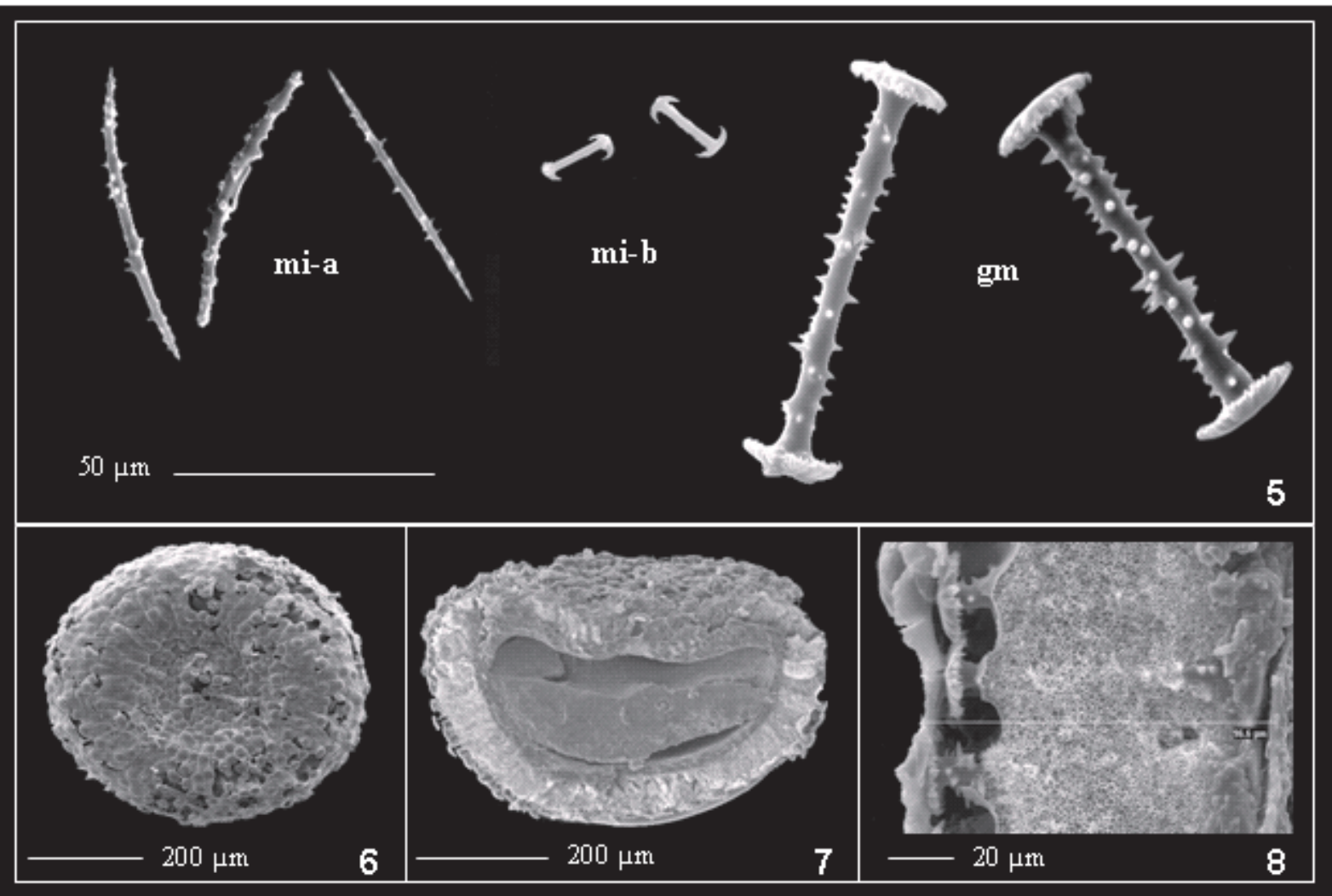

Figs. 5-8. Corvoheteromeyenia heterosclera (Ezcurra de Drago, 1974). Spicules and gemmules: 5, gemoscleres, large microscleres and small microscleres; 6 , gemmule; 7 , longitudinal section of the gemmule; 8 , detail of the pneumatic layer of the gemmule (gm, gemoscleres; mi-a, large microscleres; mi-b, small microscleres).

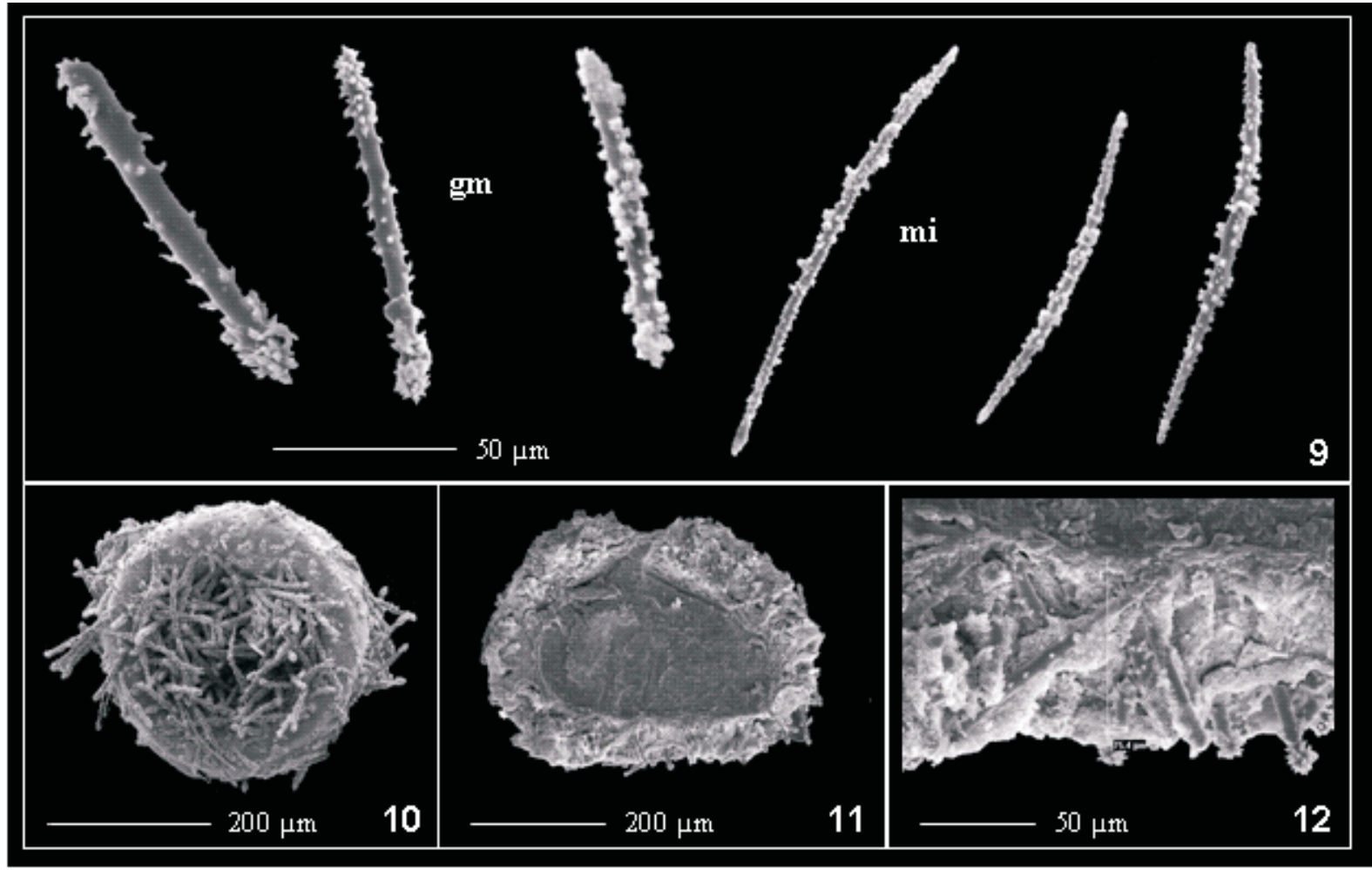

Figs. 9-12. Spongilla alba Carter, 1849. Spicules and gemmules: 9, gemoscleres and microscleres; 10, gemmule; 11, longitudinal section of the gemmule; 12, detail of the pneumatic layer of the gemmule (gm, gemoscleres; mi, microscleres). 


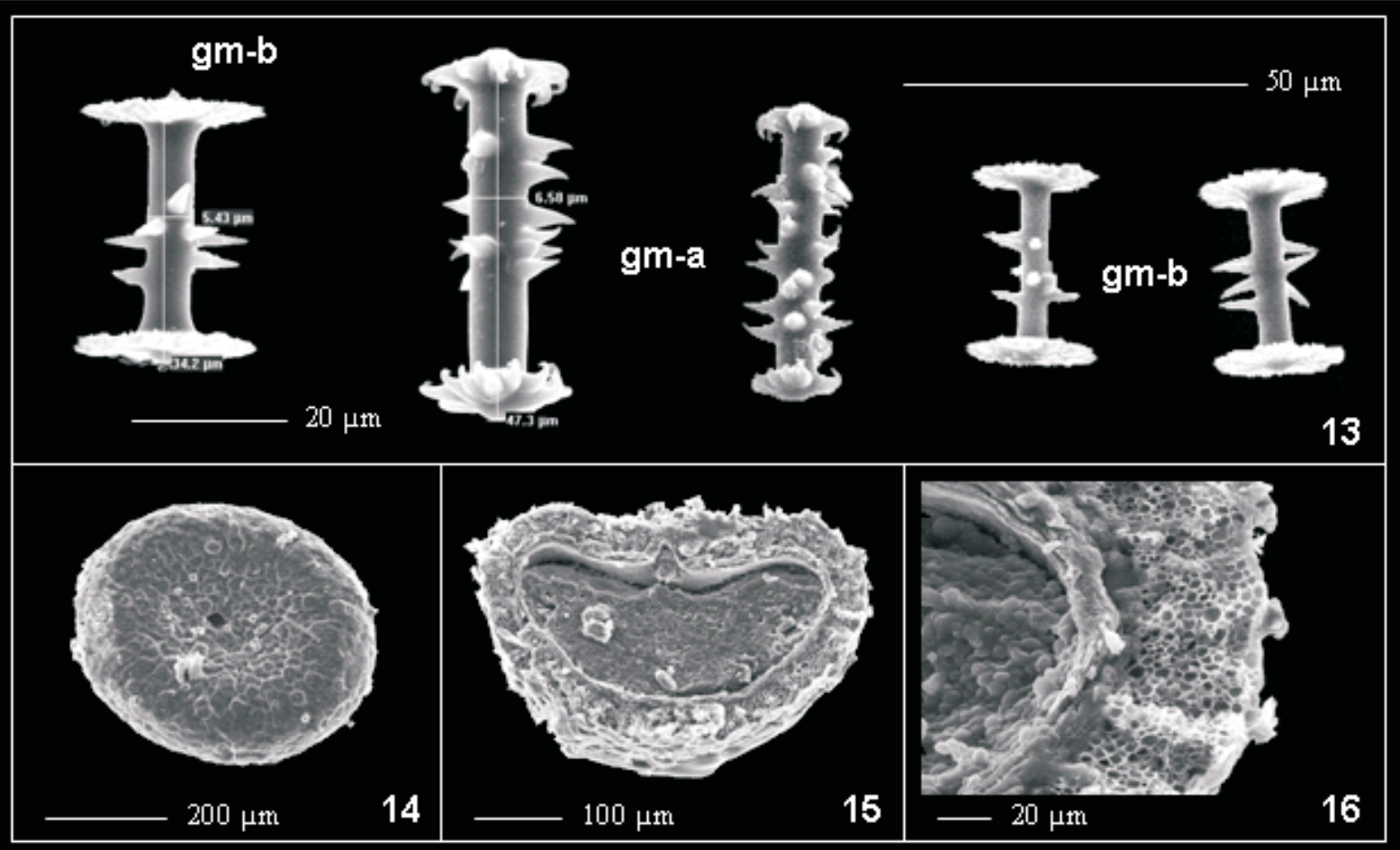

Figs. 13-16. Racekiela sheilae (Volkmer-Ribeiro et al., 1988). Spicules and gemmules: 13, large gemoscleres and small gemoscleres; 14, gemmule; 15, longitudinal section of the gemmule; 16, detail of the pneumatic layer of the gemmule (gm-a, large gemoscleres; gm-b, small gemoscleres).

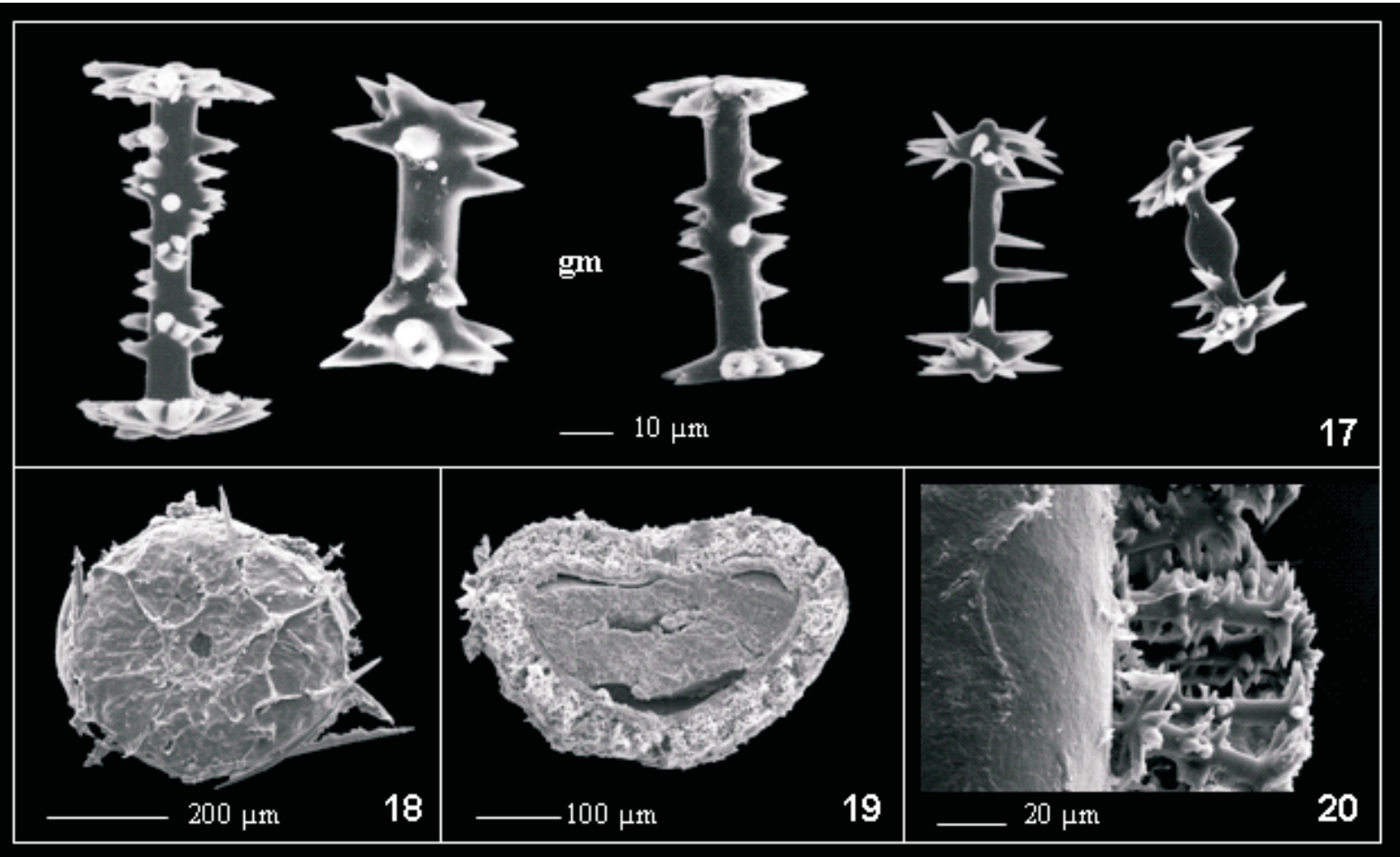

Figs. 17-20. Ephydatia facunda Weltner, 1895. Spicules and gemmules: 17, gemoscleres; 18, gemmule; 19, longitudinal section of the gemmule; 20, detail of the pneumatic layer of the gemmule (gm, gemoscleres). 


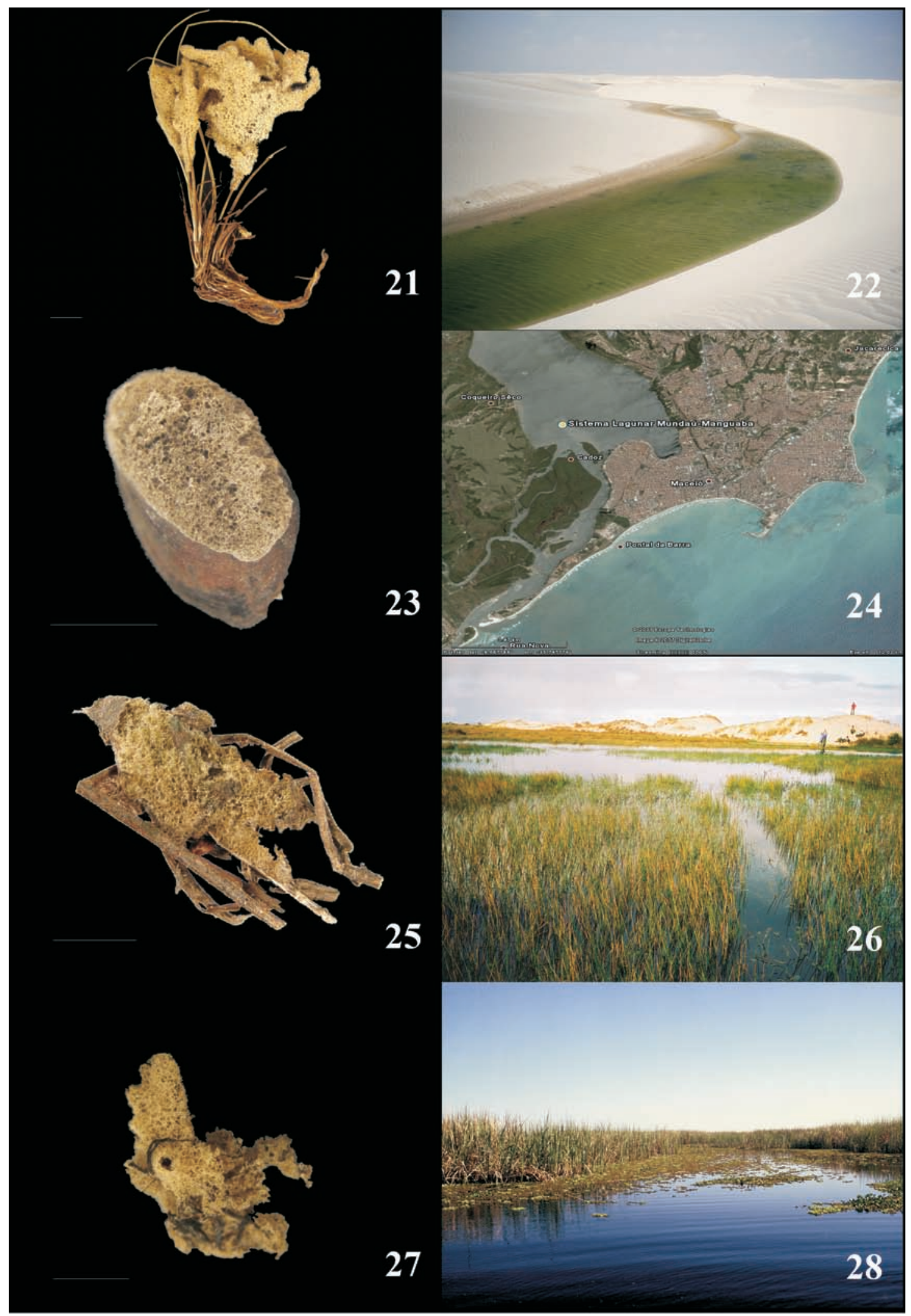

Figs. 21-28. 21, Specimen of Corvoheteromeyenia heterosclera (Ezcurra de Drago, 1974) (MCN-POR 3830); scale: 1cm. Photo V. S. Machado; 22, Lençóis Maranhenses, northeastern of Brazil, typical habitat of Corvoheteromeyenia heterosclera. Photo E. M. Brito; 23, Specimen of Spongilla alba Carter, 1849 (MCN-POR 1120); scale: 1cm. 24, Sistema Lagunar Mundaú-Manguaba, northeastern of Brazil, typical habitat of Spongilla alba. 25, Specimen of Racekiela sheilae (Volkmer-Ribeiro et al., 1988) (MCN-POR 6125); scale: $1 \mathrm{~cm}$; 26, Swampy field among dunes, Barra do Ribeiro, southern of Brazil, typical habitat of Racekiela sheilae (Photo M. P. Barros); 27, Specimen of Ephydatia facunda Weltner, 1895, (MCN-POR 1198); scale: 1cm; 28, Estação Ecológica do Taim, typical habitat of E. facunda. Photo B. Irgang. 


\section{Racekiela sheilae (Volkmer-Ribeiro, De Rosa- Barbosa \& Tavares, 1988)}

(Figs. 3, 13-16, 25, 26, 29 - 32)

Type locality. Seasonal pond with sandy/peebbled bed, on the side of the road (Figueira trail) going from the State Road RS/101, municipality of Tavares, to the Parque Nacional da Lagoa do Peixe, RS (31¹8'57,26”S; $\left.51^{\circ} 05^{\prime} 42,44^{\prime \prime} \mathrm{W}\right)$ (Figs. 30-32). The type locality was georeferenced following indications offered to the senior author by Sheila M. Pauls, in personal communication. Confirmation was at the same time obtained by the sampling of new materials and abundant gemmules at the site.

Material examined. BRAZIL, Rio Grande do Sul: Tavares (Paratype: seasonal pond alongside the road linking the town of Tavares to the Lagoa do Peixe National Park), 12.II.1984, S. M. Pauls col. (MCN-POR 1128); Bagé (marshes on the road to Forte Santa Tecla), 27.XI.1981, R. De Rosa-Barbosa col. (MCNPOR 1030); Viamão (pond at the foot of the Grota hill, Parque Estadual de Itapuã), 05.IX.1997 (MCN-POR 3777), 26.II.1998 (MCN-POR 3781, 3782), 17.III.1998 (MCN-POR 3783), C. Volkmer-Ribeiro col.; Barra do Ribeiro (swampy field among the dunes to the south of Lagoa das Capivaras), 04.VI.2003, C. Volkmer-Ribeiro \& R. De Rosa-Barbosa col. (MCN-POR 59795982), 03.VII.2003, C. Volkmer-Ribeiro col. (MCN-POR 6117 6127); Tapes (Lagoa do Charutão), 03.VI.2003 (MCN-POR 6197), 02.XII.2003 (MCN-POR 6202), C. Volkmer-Ribeiro \& R. De Rosa-Barbosa col.; (Banhado Redondo), 05.VI.2003 (MCNPOR 6207), 02.XII.2003 (MCN-POR 6210), C. Volkmer-Ribeiro \& R. De Rosa-Barbosa col.; Mostardas (seasonal pond alongside the road linking Vila de Tavares to the Parque Nacional da Lagoa do Peixe), 01.II.2006, C. Volkmer-Ribeiro \& V. S. Machado col. (MCN-POR 7161-7168); very shallow, seasonal pond at Capão Comprido (close to the Parque Nacional da Lagoa do Peixe), 01.II.2006, G. Cunha col. (MCN-POR 7169).

Description. Sponge forming extremely small, slender crusts around the stems of small macrophytes, or on stony or sandy conglomerates in, generally, very shallow waters. Living sponge creamy or greenish when associated with green algae. Dry sponge brownish-yellow (Fig. 25). Spicules of the skeleton in a confused arrangement; skeleton delicate, with conspicuous pinacoderm, riddled with megascleres. Megascleres straight or slightly curved oxeas, smooth or with scanty spines and with gradually tapering extremities. Microscleres absent. Gemoscleres, two categories of birotules, the larger, rare, even in the fully formed gemmules, with a stout shaft provided with short, strong, conical spines, concentrated at the middle portion, rotules small, umbonate, deeply cut in an irregular number of hooks turned towards the shaft; the smaller birrotules, predominant in the gemmular wall, have a slender, smooth

Table II. Spicule micrometries for Spongilla alba Carter, 1849 (Min, minimum; Max, maximum; Ave, average; SD, standard deviation): MCN-POR 1120, 1271, 1555, 3023. All measures in $\mu \mathrm{m}$.

\begin{tabular}{lcccccc}
\hline & \multicolumn{2}{c}{ Megascleres } & \multicolumn{2}{c}{ Gemoscleres } & \multicolumn{2}{c}{ Microscleres } \\
\hline & Length & Width & Length & Width & Length & Width \\
Min & 345.5 & 11.8 & 100.9 & 6.0 & 84.4 & 2.8 \\
Max & 563.5 & 46.2 & 187.3 & 11.9 & 168.8 & 7.3 \\
Ave & 449.4 & 28.5 & 136.1 & 8.7 & 128.1 & 4.7 \\
SD & 51.7 & 9.0 & 17.6 & 1.1 & 19.9 & 1.0 \\
\hline
\end{tabular}

to spiny shaft with spines also gathered at the middle portion, rotules expanded and flattened, with the border slightly to heavily indented (Fig. 13). Gemmules spherical or hemispherical (Fig. 14), provided with a short foraminal tube (Fig. 15). Gemoscleres radially embedded in the thick pneumatic layer (Fig. 16), the longest gemoscleres projecting beyond the outer gemmular coat. Spicule measurements in Table III.

VOLKMER-RibEIRo et al. (1988a) described Anheteromeyenia sheilae from scanty material collected at a seasonal pond close to the Parque Nacional da Lagoa do Peixe, State of Rio Grande do Sul. The gemmular deposit found around the marginal area of this seasonal pond (Fig. 30) enhanced the present SEM illustration of the gemmular thick pneumatic coat as well as the confirmation of the original gemmular description. This remarkable gemmular deposit discovered at the pond dry margin (Figs. 31, 32) and the absence of remaining specimens point out to the species as a r-strategist at this shallow seasonal pond. Upon restricting the genus Anheteromeyenia to species without pronounced rotules, VolKMER-RIBEIRo (1996) defined genus Acanthodiscus to contain the excluded species, one of them being $A$. sheilae in the new combination, Acanthodiscus sheilae. BASS \& VolKMER-Ribeiro (1998) detected the preocupation of the generic name Acanthodiscus and proposed the new genus Racekiela, resulting in the combination Racekiela sheilae. The genus Racekiela now includes only two species, $R$. ryderi, in the Palearctic and Nearctic Regions, and $R$. sheilae, in the Neotropical Region, to date endemic to the coastal area of Rio Grande do Sul.

Typical environment. Swampy fields (Fig. 26) or shallow ponds, close to the dune or paleodunes alignments all near the ocean border in temperate climate, (VolKMER-Ribeiro et al., 2007) (Fig. 30).

\section{Ephydatia facunda Weltner, 1895}

(Figs. 4, 17-20, 27, 28)

Material examined. BRAZIL, Alagoas: Maceió (Lagoa Mundaú-Manguaba), 20.VI.1985, G. Johnscher-Fornasaro col. (MCN-POR 1562). Rio Grande do Sul: Mostardas, schizoholotype (1 slide of spicules from the holotype, ZMB 1773), 8.XI.1892, R. von Ihering col. (MCN-POR 458); Rio Grande (Est. 30 - Lat. $31^{\circ} 23^{\prime}$ Long. 51 ${ }^{\circ} 56^{\prime} 09^{\prime \prime}$ depth. 3m, salinity 2\%), 24.V.1976, $7^{\circ}$ Cruzeiro, Projeto Lagoa dos Patos col. (MCNPOR 468); Estação Ecológica do Taim, 23.IV.1980, R. Lanzer col. (MCN-POR 769); 15.VII.1985, C. Volkmer-Ribeiro \& De Rosa-Barbosa col. (MCN-POR 1195, 1196); 23.X.1985, C. Schulz col. (MCN-POR 1197); 19.XI.1985, R. De Rosa-Barbosa col.

Table III. Spicule micrometries for Racekiela sheilae (VolkmerRibeiro et al., 1988). (Min, minimum; Max, maximum; Ave, average; SD, standard deviation): MCN-POR 1128, 5980, 6119, 6123. All measures in $\mu \mathrm{m}$.

\begin{tabular}{lcccccc}
\hline & \multicolumn{2}{c}{ Megascleres } & \multicolumn{2}{c}{ Gemoscleres small } & \multicolumn{2}{c}{ Gemoscleres large } \\
\hline \multirow{3}{*}{ Length } & Width & Length & Width & Length & Width \\
Max & 255.6 & 5.5 & 32.9 & 3.0 & 43.8 & 3.1 \\
Ave & 480.2 & 15.9 & 51.8 & 7.5 & 69.1 & 9.0 \\
SD & 458.4 & 8.9 & 40.9 & 5.1 & 57.3 & 6.6 \\
\hline
\end{tabular}


(MCN-POR 1198); 19.I.1985, R. De Rosa-Barbosa col. (MCNPOR 1199); 20.VI.1985, I. L. Mendes col. (MCN-POR 1200); 08.I.1986, R. De Rosa-Barbosa col. (MCN-POR 1267); 06.I.1986, R. De Rosa-Barbosa col. (MCN-POR 1268); 12.II.1986, R. De Rosa-Barbosa col. (MCN-POR 1286); 12.II.1986, C. Volkmer-Ribeiro col. (MCN-POR 1288); 12.XI.1986, R. De Rosa-Barbosa \& J. Pinto col. (MCN-POR 1289); 13.XI.1986, C. Volkmer-Ribeiro col. (MCN-POR 1290); 12.XI.1986, J. Pinto col. (MCN-POR 1291); 12.XI.1986, C. Volkmer-Ribeiro col. (MCN-POR 1292); 13.XI.1986, J. Pinto col. (MCN-POR 1293); 13.XI.1986, R. De Rosa Barbosa col. (MCN-POR 1294, 1295); 12.XI.1986, J. Pinto col. (MCN-POR 1295, 1296); 12.XI.1986, R. De Rosa-Barbosa col. (MCN-POR 1297, 1299); 06-07.I.1987, R. De Rosa-Barbosa col. (MCNPOR 1300 - 1307).
Description. Sponges spherical, sub-spherical or forming irregular crusts on hard substrates but mainly on submerged portions of aquatic vegetation. Dry sponges brittle, drab yellow; living sponges sparkling white fragile and compressible (Fig. 27). Skeleton a confused reticulation of short monospicular fibers, with abundant spongin, dermal membrane conspicuous and heavily encrusted with megascleres. Oscules of varying sizes, also conspicuous oscular areas may be present. Megascleres oxeas straight to slightly curved, smooth, little or totally microspined and gradually tapering. Microscleres absent. Gemoscleres birotules, with variation in size and shape, delicate or robust, with short

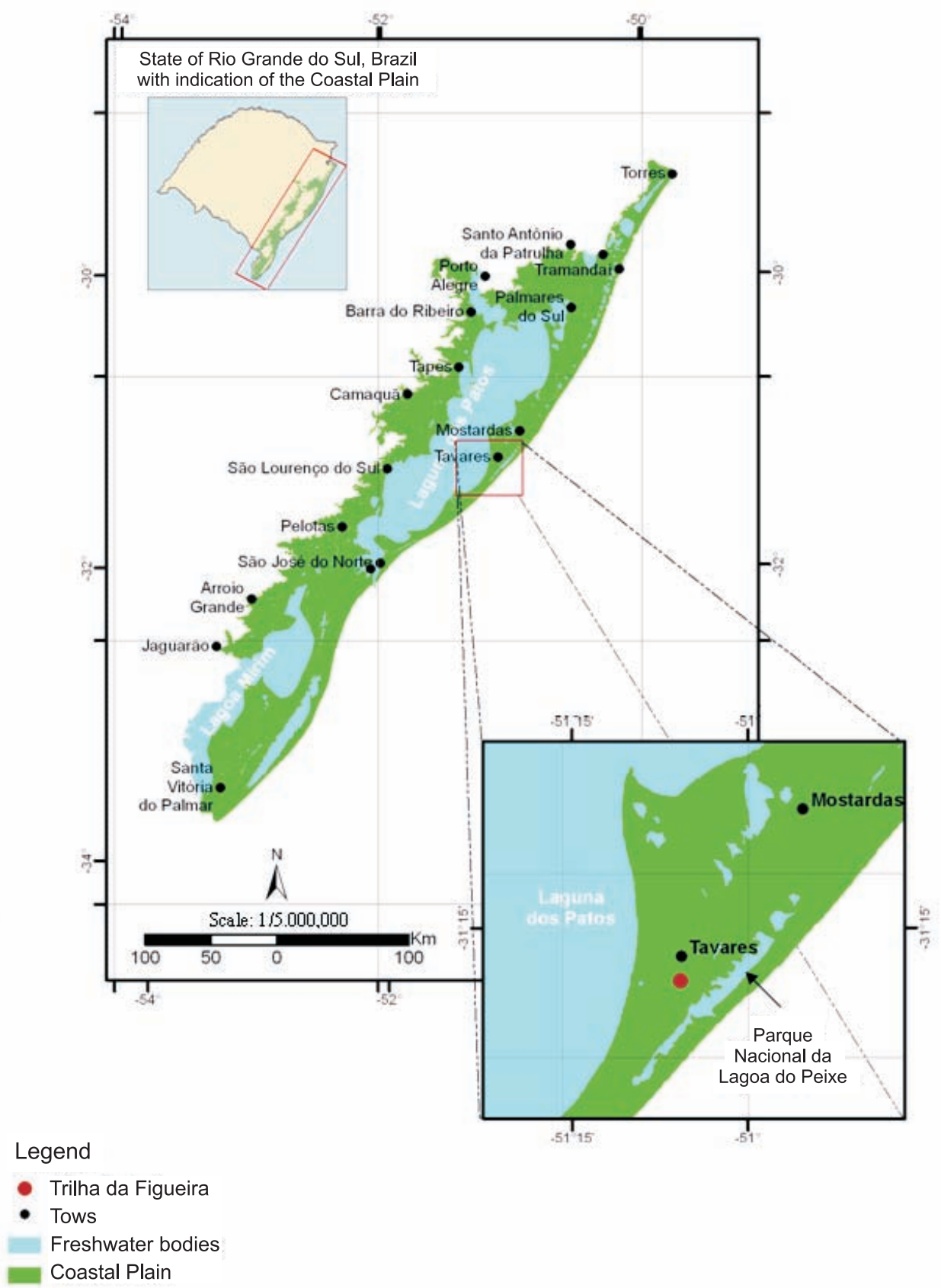

Fig. 29. Map with the type locality of Racekiela sheilae (Volkmer-Ribeiro et al., 1988): seasonal pond with sandy/peebbled bed, municipality of Tavares, close to the Parque Nacional da Lagoa do Peixe, State of Rio Grande do Sul. 
or long heavily spined or smooth shafts; rotules flat and expanded, irregularly cut in few or many straight or curved spines disparate in size and shape (Fig. 17). Gemmules whitish, abundant, spherical or hemispherical (Fig. 18), the fully formed ones with a thick outer layer. Foraminal tube short, contained inside the thick pneumatic coat (Fig. 19), gemoscleres radially arranged in the pneumatic coat (Fig. 20). Spicule measurements in Table IV.

The species is dominant in the lakes and swamps of the Estação Ecológica do Taim (Fig. 28), with occurrence proven by the collection of numerous specimens of various sizes and shapes, in all habitats present in this coastal freshwater system, with gemmules formed mainly in November, when the largest specimens were also found. At this system the submerged roots of the floating macrophytes are the available substrate for the sponges and were seen to be used in the following order of frequency: Eichhornia azurea, E. crassipes, Pistia stratiotes and Ceratophylum demersum (VOLKMERRiBEIRO et al., 1988a). These authors concluded that $E$. facunda was a species occuring in lagoonal or swampy coastal areas at Rio Grande do Sul.

Subsequently, VOLKMER-RIBEIRo \& TAVARES (1990) registered E. facunda for the Sistema Lagunar MundaúManguaba, State of Alagoas. More recently, PinHEIRo et al. (2004) extended this last record to the Rio Niquin, in the municipality of Barra de São Miguel, Alagoas, though in conditions similar to those found in the aforementioned complex. In spite of its abundance in freshwater habitats E. facunda stands mesohaline environments as those of the Sistema Lagunar Mundaú-Manguaba, however with a remarkable preference for the organically enriched habitats at all the registered environments. VOLKMERRIBEIRO et al. (2006) used gemoscleres of E. facunda contained in the recent sediments of distinct aquatic habitats at the Taim wetland system and demonstrated the validity of using freshwater sponge spicules in paleointerpretation and the study of evolution of coastal waters in South America.

Typical environment. The species is thus characterized as occupying environments with extensive macrophyte coverage (Fig. 28). Due to their association with abundant aquatic vegetation, the waters occupied are generally acid and brownish to black in colour, as a result of the abundance of humic substances and organic material in the sediments. This last association is well characterized in the study of the content of the spicules of E. facunda in recent sediments of the Estação Ecológica do Taim (VolkMER-RIBEIRo et al., 2006).

Table IV. Spicule micrometries for Ephydatia facunda Weltner, 1895. (Min, minimum; Max, maximum; Ave, average; SD, standard deviation): MCN-POR 468, 1198, 1200, 1268. All measures in $\mu \mathrm{m}$.

\begin{tabular}{lcccc}
\hline & \multicolumn{2}{c}{ Megascleres } & \multicolumn{2}{c}{ Gemoscleres } \\
\hline & Length & Width & Length & Width \\
Min & 266.0 & 7.0 & 92.1 & 6.4 \\
Max & 514.6 & 19.2 & 92.1 & 6.4 \\
Ave & 368.6 & 12.6 & 61.6 & 4.1 \\
SD & 43.2 & 2.4 & 11.7 & 0.6 \\
\hline
\end{tabular}

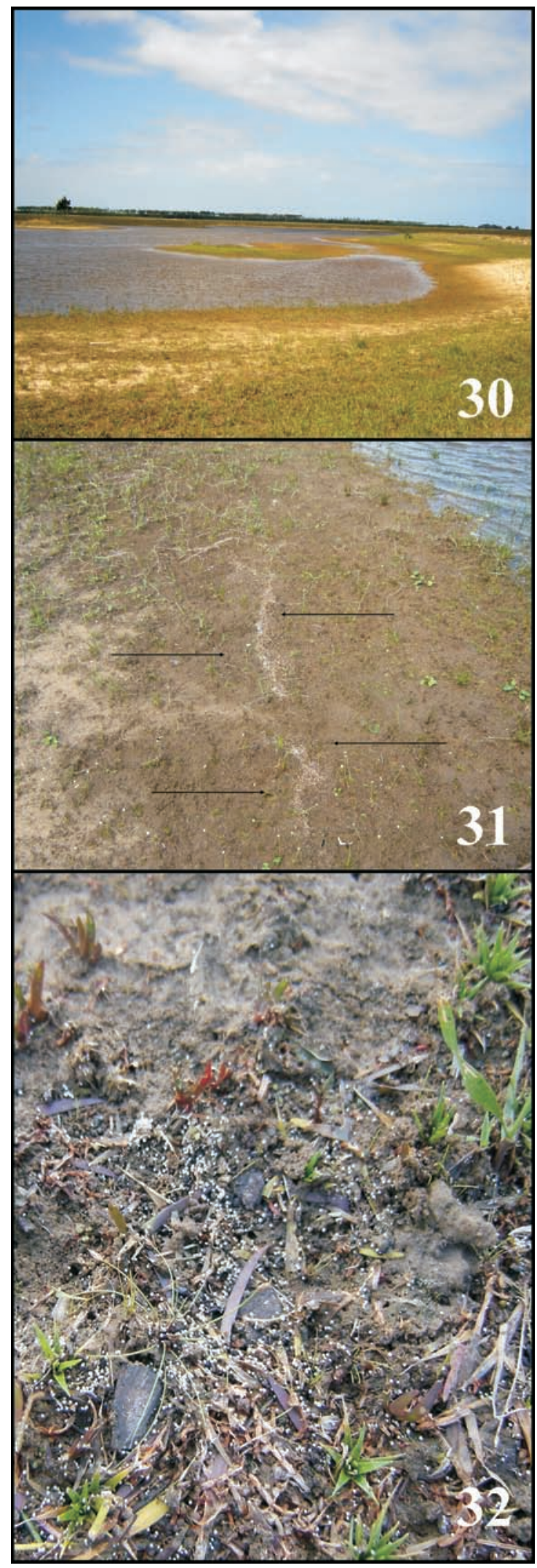

Figs. 30-32. 30, Seasonal pond and type locality of Racekiela sheilae: alongside the road (Figueira trail) linking Tavares to the Parque Nacional da Lagoa do Peixe, State of Rio Grande do Sul. Photo V. S. Machado; 31, Remarkable gemmular deposit discovered at the pond dry margin; 32, Detail of the amount of $R$. sheilae gemmules recently produced and deposited at the pond dry edge. 
Acknowledgements. The authors thank CNPq and FAPERGS for the CV-R researcher fellowship and VSM IC fellowship, respectively. The authors are grateful to M. Sc. Maria Tereza Queiroz Melo, Director of the Parque Nacional da Lagoa do Peixe, Mostardas, RS, for logistic support at field work. They are indebted to Mariano Cordeiro Pairet Jr. for photographs $n^{\circ} \mathrm{s}$ 31 and 32, to Marcelo P. Barros for photograph $\mathrm{n}^{\circ} 26$, to Rosana Moreno Senna for photograph $n^{\circ} 28$ taken by her deceased husband Prof. Bruno Irgang. To Carolina Coimbra Mostardeiro (IC fellow of CNPq), Rejane Rosa (art assistant) and the staff of the Laboratório de Geoprocessamento, all at Museu de Ciências Naturais, Fundação Zoobotânica do Rio Grande do Sul, for respectively, the measurements of the spicules, the final artwork of the drawings in figures 1-4, the map and the processing of the image in figure 24. They also acknowledge Edilson Morais Brito for photograph $\mathrm{n}^{\circ} 22$. Last, but not least, the authors thank Dr. Eduardo Hajdu, Museu Nacional, UFRJ and an anonymous referee for the valuable suggestions offered

\section{REFERENCES}

Bass, D. \& VolKMER-RIBEIRo, C. 1998. Radiospongilla crateriformis (Porifera, Spongillidae) in the West Indies and taxonomic notes. Iheringia, Série Zoologia, 85:123-128.

Batista, T. C. A. \& Volkmer-Ribeiro, C. 2002. Comunidades de esponjas do curso superior dos rios Paraná (Goiás) e Paraguai (Mato Grosso), Brasil, com redescrição de Oncosclera schubarti (Bonetto \& Ezcurra de Drago). Revista Brasileira de Zoologia 19(1):123-136.

Batista, T. C. A.; Volkmer-Ribeiro, C.; Darwich, A. \& Alves, L. F. 2003. Freshwater sponges as indicators of floodplain lake environments and of river rocky bottoms in Central Amazonia. Amazoniana XVII(3/4):525-549.

Bonetto, A. A. \& Ezcurra de Drago, I. 1970. Esponjas de los afluentes del Alto Paraná en la Provincia de Misiones. Acta Zoologica Lilloana XXVII:37-58.

Candido, J. L.; Volkmer-Ribeiro, C.; Simões Filho, F. L.; Turce, B. J. \& Chauvel, A. 2000. Microsclere variations of Dosilia pydanieli (Porifera, Spongillidae) in Caracaranã lake (Roraima - Brazil). Palaeoenvironmental implication. Biociências 8(2):77-92.

Ezcurra de Drago, I. 1974. Las espécies sudamericanas de Corvomeyenia Weltner (Porifera: Spongillidae). Physis B 33(87):233-240.

Gaiser, E. E.; Brooks, M. J.; Kenney, W. F.; Schelske, C. L. \& TAYLOR, B. E. 2004. Interpreting the hydrological history of a temporary pond from chemical and microscopic characterization of silicious microfossils. Journal of Paleolimnology 1:63-76.

Harrison, F. W. 1974. Porifera. In: Hart, C.W. \& Fuller, S. L. H. eds. Pollution Ecology of fresh-water Invertebrates. New York, Academic. p.29-66.

1988. Utilization of freshwater sponges in paleolimnological studies. Palaeogeography, Palaeoclimatology, Palaeoecology 62:387-397.

Penney, J. T. \& RaceK, A. A. 1968. Comprehensive revision of a worldwide collection of freshwater sponges (Porifera: Spongillidae). Proceedings of the United States National Museum 272:1-184.

Pinheiro, U. S.; Hajdu, E. \& Correa, M. D. 2004. First description of gemmules of Ephydatia facunda Weltner, 1895 (Porifera, Haplosclerida, Spongillidae) by scanning electron microscopy, with underwater observation of a large population from northeastern Brazil. Journal of Natural History 38:1071-1080.

Poirrier, M. A. 1976. A taxonomic study of the Spongilla alba, S. cenota, S. wagneri species group (Porifera - Spongillidae) with ecological observations of S. alba. In: HaRRISON, F. W. \& Cowden, R. R. eds. Aspects of sponge biology. New York, Academic. p.203-213.
Tavares, M. C. M.; Volkmer-Ribeiro, C. \& De Rosa-Barbosa, R. 2003. Primeiro registro de Corvoheteromeyenia australis (Bonetto \& Ezcurra de Drago) para o Brasil com chave taxonômica para os poríferos do Parque Estadual Delta do Jacuí, Rio Grande do Sul, Brasil. Revista Brasileira de Zoologia 20(2):169-182.

Termier, H. \& Termier, G. 1963. Erosion and sedimentation. London, D. Van Nostrand. 433p.

TurcQ, B.; Sifeddine, A.; Martin, L.; Absy, M. L.; Soubies, F.; Souguio, K. \& Volkmer-Ribeiro, C. 1998. Amazon Forest fires: a lacustrine report of 7,000 years. Ambio 27(2):139-142.

Volkmer-Ribeiro, C. 1985. Manual de técnicas para a preparação de coleções zoológicas 3. São Paulo, Sociedade Brasileira de Zoologia, CNPq. 6p.

1996. Acanthodiscus new genus and genus Anheteromeyenia redefined (Porifera, Spongillidae). Iheringia, Série Zoologia, 81:31-43.

Volkmer-Ribeiro, C. \& Almeida, F. B. de. 2005. As esponjas do Lago Tupé. In: Santos-Silva, E.; Aprile, F. M.; Scudeller, V. V. \& Melo, S. eds. BioTupé: meio físico, diversidade biológica e sociocultural do Baixo Rio Negro, Amazônia Central. Manaus, INPA, p. 123-134.

Volkmer-Ribeiro, C. \& MotTA, J. F. M. 1995. Esponjas formadoras de espongilitos em lagoas no Triângulo Mineiro e adjacências, com indicação de preservação de habitat. Biociências 3(2): $145-169$.

VolKmer-Ribeiro, C. \& Pauls, S. M. 2000. Esponjas de agua dulce (Porifera, Demospongiae) de Venezuela. Acta Biologica Venezuelica 20(1):1-28.

Volkmer-Ribeiro, C. \& Reitner, J. 1991. Renewed study of the type material of Palaeospongilla chubutensis Ott and Volkheimer (1972). In: Reitner, J. \& Keupp, H. eds. Fossil and Recent Sponges. Berlin, Springer. p.121-133.

Volkmer-Ribeiro, C. \& Tavares, M. C. M. 1990. Esponjas de água doce do complexo Lagunar Mandaú-Manguaba e dos seus rios formadores; Alagoas, Brasil. Iheringia, Série Zoologia, 70:171-172.

Volkmer-Ribeiro, C. \& Traveset, A. 1987. Annotated catalog of the type specimens of Potts' species of freshwater sponges. Proceedings of The Academy of Natural Sciences of Philadelphia 139:223-242.

VolKmer-Ribeiro, C. \& TurCQ, B. 1996. SEM analysis of siliceous spicules of a freshwater sponge indicate paleoenvironmental changes. Acta Microscopica 5(B):186-187.

Volkmer-Ribeiro, C.; De Rosa-Barbosa, R. \& Mostardeiro, C. C. 2007. Esponjas. In: BeCKer, F. G.; RAmos, R. A. \& Moura, L. DE A. orgs. Biodiversidade da região dos Butiazais de Tapes e da Lagoa do Casamento, Planície Costeira do Rio Grande do Sul. Brasília, MMA/SBF. p.154-161.

Volkmer-Ribeiro, C.; De Rosa-Barbosa, R. \& Tavares, M. C. M. 1988a. Anheteromeynia sheilae sp. n. e outras esponjas dulciaquícolas da região costeira do Rio Grande do Sul (Porifera, Spongillidae). Iheringia, Série Zoologia, 68:83-98.

Volkmer-Ribeiro, C.; Correia, M. M. F.; Brenha, S. L. A. \& MendonçA, M. A. 1999. Freshwater sponges from a Neotropical sand dune area. Memoirs of the Queensland Museum 44:643-649.

Volkmer-Ribeiro, C.; Mansur, M. C. D.; Mera, P. A. S. \& Ross, S. M. 1988b. Biological indicators in the aquatic habitats of the Ilha de Maracá. In: Milliken, W. \& RatTeR, J. A. eds. Maracá - The biodiviersity and environment of an Amazonian Rainforest. Chichester, John Willey Sons. 508p.

Volkmer-Ribeiro, C.; Marques, D. M.; De Rosa-Barbosa, R. \& Machado, V. S. 2006. Sponge spicules in sediments indicate evolution of coastal freshwater bodies. Proceedings ICS 2004, Journal of Coastal Research 39:469-472.

WeltNer, W. 1895. Spongillidenstudien III. Katalog und Verbreitung der bekannten Süsswasserschswämme. Archiv für Naturgeschichte 61(1):114-144. 